\title{
IDENTIFIKASI FRAKSI AIR SENYAWA ANTIOKSIDAN MINUMAN SINOM (Curcuma domestica Val.- Tamarindus indica L.)
}

\author{
Purwaningtyas Kusumaningsih, Ni Ketut Wiradnyani \\ Program Studi Ilmu Gizi, Fak. Ilmu Kesehatan Sains dan Teknologi, Universitas Dhyana \\ Email: purwak.05@undhirabali.ac.id
}

\begin{abstract}
ABSTAK
Sinom meminum makanan fungsional analternatif. Bahan-bahannya adalah curcumin dan daun tamarin muda, mudah didapat, relatif mahal yang dikonsumsi, mengandung senyawa antioksidan. Penelitian ini bertujuan untuk mengidentifikasi senyawa antioksidan minuman sinom terhadap perlakuan fraksi pelarut air secara in vitro. Dengan metode analisis GCMS dan TLC. Kapasitas antioksidan dalam fraksi minuman sinom air (13,91\%) adalah AAEAC 1990,9 ppm dan hasil (10,94\%). Fraksi air mengandung senyawa: asam lemak 9-oktadecanoid $(69,43 \%)$, asam askorbat $(32,7 \%)$, Ribovlafin $(37,1 \%)$, ar-tumeron $(1,31 \%)$, tumeron $(2,85) \%)$ dan curlon $(1,09 \%$.). Penelitian ini dengan analisis blok acak. Hasil penelitian menunjukkan fraksi air minuman sinom mengandung senyawa: asam lemak 9-oktadecanoid, asam askorbat, ribovlafin, artumeron, tumeron dan curlon.
\end{abstract}

Kata kunci: Minuman Sinom, fraksi pelarut air, kapasitas antioksidan, Identifikasi

\section{ABSTRACT}

Sinom beverages analternative functional food. The ingredients are curcumin and young tamarin leaves, it is easily available, relatively in expensive expected that is consumed, it contains antioxidant compounds. This study aimed to identification of sinom beverages antioxidant compounds to treatment of water solvent fraction in vitro. With GCMS and TLC analysis of method. The antioxidant capacity in beverages sinom water fraction (13,91\%) is 1990,9 ppm AAEAC and yield (10,94\%). The water fraction contain compounds: 9-oktadecanoid fatty acids (69,43\%), ascorbic acid (32,7\%), Ribovlafin (37,1\%), ar-tumeron (1,31\%), tumeron $(2,85 \%)$ and curlon $(1,09 \%$.). This research with randomized block analysis. The results showed water fraction of sinom beverages contains compound: 9-oktadecanoid fatty acids, ascorbic acid, Ribovlafin, ar-tumeron, tumeron and curlon.

Keywords: Sinom beverage, water solvent fraction, antioxidant capacity, Identification

\section{PENDAHULUAN}

Secara alamiah kunyit dipercaya memiliki kandungan fitokimia yang dapat berfungsi sebagai analgetika, antipiretika, dan antiinflamasi Norton (2008), begitu juga daun asam muda (asam jawa) kaya akan flavonoid, fenol dan saponin Mursit (2004). Minuman sinom berasal dari campuran kunyit dengan daun asam, dalam bentuk cair telah diuji aktivitas antioksidan oleh Mulyani et al. (2010). Pengujian ini dilakukan untuk mengetahui aktivitas antioksidan minuman sinom terhadap daya hambat proses oksidasi lemak. Hasilnya menunjukkan bahwa ekstrak kunyit dalam pelarut $50 \%$ etanol menghasilkan produk ekstrak kunyit dengan aktivitas antioksidan $1,13 \%$, sedangkan ekstrak daun asam dalam pelarut $70 \%$ etanol mempunyai aktivitas antioksidan 0,123\%. Resi (2012) menunjukkan bahwa formula minuman fungsional campuran kunyit $10 \%$ dan asam jawa $5 \%$ (v/v) merupakan minuman kunyit asam terpilih yang memiliki kapasitas antioksidan 99,594 ppm AAE dan kadar total fenol 97,451 ppm. Namun senyawa penyusun minuman sinom fraksi air sebagai antioksidan belum diketahui dengan pasti.Tujuan penelitian ini adalah menentukan nilai kapasitas dan senyawa penyusun antioksidan fraksi air minuman sinom.

\section{METODE}

Bahan

Bahan yang dipergunakan dalam penelitian yaitu rimpang kunyit yang diperoleh dari pasar tradisional Badung, Denpasar, Bali, dengan ukuran panjang 10-15 cm dan diameter $1 \mathrm{~cm}$, warna kuning tua. Daun asam yang masih muda dari pucuk daun sampai helai daun ke-tujuh dari daerah Buduk, Mengwi, Badung, Bali. Semua bahan kimia yang dipergunakan adalah grade pa E.Merck yaitu : Nicotinic acid, B2 vitamin powder, tablet poly vitamin, Silika gel GF254 (Merck) dengan ukuran $20 \mathrm{~cm}$ x $20 \mathrm{~cm}$.

\section{Alat \\ Alat yang dipergunakan dalam penelitian yaitu spektrofotometer (Shimadzu UV-160), GC- MS (Agilent Technologie dengan kolom Hp 5MS,}


30 m), Thin Layer Cromatography (TLC) Spektrofotometer dengan scanner (Camag), rotary vacum evaporator (IK RV 10), labu pisah, Erlenmeyer $250 \mathrm{ml}$ (Pyrex), vortex, elution chamber.

\section{Tempat penelitian}

Penelitian dilakukan di Laboratorium Pengolahan Pangan Fakultas Teknologi Pertanian Universitas Udayana, Laboratorium Kimia Forensik Polri Bali. Laboratorium.

\section{Pelaksanaan penelitian}

Penelitian ini dimulai dengan penyiapan minuman sinom dilakukan dengan cara: rimpang dikupas, ditimbang sebanyak 50 gram, dicuci, diblender dengan menambahkan $400 \mathrm{ml}$ air selama 3,5 menit kemudian disaring dipanaskan sampai mendidih, 1 menit. Filtrat yang diperoleh disebut filtrat kunyit. Filtrat daun asam muda yang dibuat dengan cara ditimbang seberat 250 gram daun asam muda, ditambahkan $300 \mathrm{ml}$ perbandingan 5: 6 (b/v) air, kemudian dipanaskan dan dibiarkan mendidih sampai 1 menit. Minuman sinom yang sudah disaring, menghasilkan filtrat kunyit $350 \mathrm{ml}$ dan 275 dari daun asam, dimasukan ke dalam botol kaca, siap digunakan untuk pengujian. (Mulyani, et al., 2014)

Fraksinasi minuman sinom dengan menggunakan 4 pelarut yaitu heksana, cloroform, etil asetat dan pelarut air dilakukan sebagai berikut: $100 \mathrm{ml}$ minuman sinom dimasukan ke dalam corong pisah yang telah dikeringkan dalam oven selama 15 menit pada suhu $100^{\circ} \mathrm{C}$, selanjutnya ditambahkan satu persatu berbagai pelarut masing-masing $100 \mathrm{ml}(1: 1 \mathrm{v} / \mathrm{v})$ dikocok $10 \mathrm{kali}$ dan didiamkan selama 30 menit. Fraksi air dipisahkan selanjutnya dievaporasi pada suhu $45^{\circ} \mathrm{Cdan}$ tekanan 280 mbar untuk menghilangkan pelarut.

\section{Penentuan standar}

Asam askorbat digunakan sebagai pembanding kontrol positip yang dibuat dengan cara dilarutkan dalam pelarut metanol dengan konsentasi 0, 10, 20, 40, 60, 80, dan 100 ppm. Larutan DPPH yang digunakan disiapkan dengan menggunakan kristal DPPH dalam pelarut metanol dengan konsentrasi $1 \mathrm{mM}$. Proses pembuatan larutan DPPH $1 \mathrm{mM}$ dilakukan dalam kondisi suhu rendah $27^{\circ} \mathrm{C}$ dan terlindung dari cahaya matahari. Absorbansi larutan blanko diukur untuk melakukan persen inhibisi. Larutan blanko dibuat dengan mereaksikan $0.5 \mathrm{ml}$ pelarut metanol dengan $3.5 \mathrm{ml}$ larutan DPPH $1 \mathrm{mM}$ dalam tabung reaksi tertutup. Uji antioksidan fraksi minuman sinom (Muhtadi,et al, 2014)

Masing-masing fraksi minuman sinom ditimbang sebanyak $1 \mathrm{~g}$ kemudian dilarutkan dalam metanol $100 \%$ sebanyak $10 \mathrm{ml}$, lalu divortex dan disaring. Fraksi minuman sinom, dan larutan DPPH yang telah dibuat, masing-masing diambil $0.5 \mathrm{ml}$, dan kemudian direaksikan 3,5 $\mathrm{ml}$ larutan DPPH $1 \mathrm{mM}$ dalam tabung reaksi tertutup yang berbeda yang telah diberi label. Campuran tersebut kemudian diinkubasi pada suhu ruang selama 30 menit dan diukur absorbansinya dengan menggunakan spektrofotometer pada panjang gelombang $517 \mathrm{~nm}$. Setelah itu, aktivitas antioksidan dari masing - masing sampel dinyatakan dengan persen inhibisi yang dihitung dengan rumus berikut:

Regresi : $\mathrm{Y}=\mathrm{ax}+\mathrm{b}$.

Rumusnya $($ ppmAAEAC $)=\underline{\text { konsntrasi }(p p m) \times \text { Tv } \times \text { Fp } \times 1000.000}$

Keterangan : $\mathrm{Tv}=$ total volume (liter), $\mathrm{Fp}=$ faktor pengeceran, Konsentrasi $=$ hasil penghitungan kurva standar, AAEAC $=$ Ascorbic Acid Equivalent Antioksidan Capacity.

\section{Identifikasi fraksi air minuman sinom.}

Identifikasi fraksi air minuman sinom dengan metode GCMS melalui preparasi sampel dengan Solid Phase Extraction (SPE) (Suaniti et al., 2013). Fraksi air minuman sinom dipreparasi dengan menyiapkan kolom isian SPE $10 \mathrm{ml}$, dituangkan 10 ml sampel ke dalam kolom, dibiarkan 10 menit, dituangkan $20 \mathrm{ml}$ pelarut sesuai dengan jenis pelarut , ,ditampung eluen ke dalam baker glass $100 \mathrm{ml}$, eluen dikeringkan hingga $1 \mathrm{ml}$ untuk menghilangkan pelarutnya. Sampel siap dianalisis dengan GCMS dan $T L C$

\section{Identifikasi senyawa dengan TLC.}

Pada uiji identifikasi senyawa dengan menggunakan metode Thin Layer Chromatography ( $T L C$ ) fraksi air, diggunakan standar Vitamin $\mathrm{C}$ dan Vitamin B sebagai berikut: eluen sebanyak 5 $\mathrm{ml}$ untuk elusi chamber, dan didiamkan selama 1520 min, eluen dijenuhkan dengan uap pelarut di ruang elusi. Setengah dari tablet yang digunakan sebagai standar dihaluskan dengan mortar dan ditambahkan $5 \mathrm{ml}$ air suling, filtrat dilarutkan ke dalam gelas kimia. Ditandai tempat sampel yang akan ditotolkan, titik-titik disebelahnya harus 
diberi jarak sekitar $10 \mathrm{~mm}$, minimal $5 \mathrm{~mm}$ dari pelat tepi. Senyawa zat yang tidak diketahui ditotolkan lagi dari garis awal. Standar ditotolkan pada plat kaca ditambahkan setetes air suling. Totol dikerok kemudian di tambahkan pelarut metanol. Sampel siap di analisis dengan spektrofotometer.

Identifikasi senyawa fraksi minuman sinom dengan GS-MS (Anonim ${ }^{1}, 2015$ ). Kondisi oprasional GCMS adalah sebagai berikut : GCMS merek Agilent Technologie dengan kolom HP 5 MS, $30 \mathrm{~m}$, ID $0,25 \mathrm{~mm}$, program $100^{\circ}(4 \mathrm{~min})$, $10^{\circ} / \mathrm{min}, \quad$ suhu oven $280^{\circ} \mathrm{C} \quad(5 \mathrm{~min})$, suhu injektornya $260^{\circ} \mathrm{C}$, laju alir carrier $1,5 \mathrm{ml} / \mathrm{mm}$, gas pembawa Helium. Program MS nya sendiri terdiri dari suhu ion source $250^{\circ} \mathrm{C}$, suhu quadrapole: $230^{\circ} \mathrm{C}$, Energi $152 \mathrm{~g}$ eu volt, rapellernya 32,1, ion focus adalah 90,2. Fraksi air yang terbaca oleh GCMS karena diuapkan terlebih dahulu selama 12 jam, kemudian dilarutkan kembali ke dalam methanol. Selanjutnya diuji dengan menggunakan GCMS.

\begin{abstract}
Analisis Data
Identifikasi senyawa penyusun minuman sinom dianalisis dengan menggunakan perangkat lunak Wiley 229, NIST 12, dan NIST 62 Library dengan kemiripan minimal $90 \%$.
\end{abstract}

\section{HASIL DAN PEMBAHASAN}

Analisis keragaman pada Rancangan Acak Lengkap menunjukkan bahwa perlakuan berbagai pelarut berpengaruh nyata $(\mathrm{p}<0,05)$ terhadap kapasitas antioksidan fraksi pelarut minuman sinom. Hasil perbandingan berganda BNT menunjukkan bahwa fraksi pelarut saling menunjukkan perbedaan yang nyata pada rata-rata kapasitas antioksidan yang dihasilkan berturut-turut adalah heksana $(4,84 \%)$, Kloroform $(3,52 \%)$, etil asetat $(3,33 \%)$ dan air $(13,91 \%)$. Hasil analisis kapasitas berbagai pelarut terlihat pada |Tabel 1.

Tabel 1. Rata-rata Rendemen (\%) dan Kapasitas Antioksidan ( $\mu$ g AAEAC/g bahan) Perlakuan Jenis Pelarut Minuman sinom

\begin{tabular}{lcc}
\hline Pelarut & $\begin{array}{c}\text { Rata-rata Rendemen } \\
(\%)\end{array}$ & $\begin{array}{c}\text { Rata-rata Antioksidan } \\
(\mu \mathrm{g} \text { AAEAC/g bahan })\end{array}$ \\
\hline Heksan & $8,01^{\mathrm{c}}$ & $42.800^{\mathrm{d}}$ \\
Cloroform & $9,99^{\mathrm{b}}$ & $94.200^{\mathrm{b}}$ \\
til Asetat & $2,04^{\mathrm{d}}$ & $66.600^{\mathrm{c}}$ \\
Air & $10,94^{\mathrm{a}}$ & $199.100^{\mathrm{a}}$ \\
\hline
\end{tabular}

Notasi huruf yang berbeda dalam kolom yang sama menunjukkan perbedaan yang signifikan pada $p<0,05(B N T)$

Fraksi air minuman sinom mempunyai kapasitas antioksidan yang paling tinggi dibandingkan dengan fraksi yang lainya diduga karena adanya senyawa yang berperan sebagai antioksidan terdiri dari vitamin $C$ dan vitamin $B_{2}$ yaitu Ribovlafin dari hasil uji Kromatograpi Lapis Tipis (KLT)/TLC (Tabel 2) sebagai senyawa yang bersifat polar yang dapat larut dalam air. Hasil uji dari GCMS menunjukkan bahwa 9-octadecenoid acid senyawa antioksidan dengan konsentrasi tertinggi pada fraksi air adalah dari asam lemak yaitu MUFA yang merupakan omega-9 Christie (2013) disamping senyawa ar- tumeron, tumeron dan Curlon sebagai senyawa fenol berasal dari golongan kurkumin. Hal ini didukung oleh Kumalaningsih (2006) yang menjelaskan bahwa senyawa-senyawa yang diduga sebagai penyusun fraksi air minuman sinom itu bersinergi untuk mengkelat radikal bebas secara bersama-sama sehingga kinerja senyawa yang tergabung di dalamnya memiliki kemampuan yang efektif dalam menangkal radikal bebas.
Reaksi yang terjadi pada metode DPPH adalah transfer elektron (ET) yang ditandai dengan perubahan warna atau tidak ada penilaian terhadap kompetisi reaksi kinetik seperti pada reaksi Hydrogen Atom Transfer (HAT) (Huang et al., 2005). Pengukuran aktivitas antioksidan minuman sinom dilakukan dengan metode DPPH $(1,1$ diphenyl-2picryl-hidrazyl) karena metode ini sudah umum digunakan, karena praktis dalam pelaksanaan, dan waktunya relatif cepat. DPPH merupakan suatu senyawa radikal bebas yang bersifat stabil (Vaya dan Aviram, 2002). Prinsip kerjanya adalah adanya suatu elektron antioksidan yang memberikan elektron (hidrogen) melalui reaksi elektron transfer (reaksi redok) kepada oksidan seperti DPPH, yang mengakibatkan terjadinya perubahan warna.

Warna violet (DPPH radikal) yang dimilikinya setelah bereaksi dengan suatu antioksidan akan memudar atau menghilang menjadi warna kuning. Perubahan reaksi awal saat penambahan DPPH pada minuman sinom yang 
diuji, ketika nilai absorbansi menurun menandakan bahwa semakin banyaknya antioksidan yang terdapat pada minuman sinom. Hal ini didukung oleh (Molyneux, 2003; Vaya dan Aviram, 2002; Huang et al., 2005).

Senyawa yang diduga sebagai penyusun fraksi air minuman sinom, yang memiliki aktivitas antioksidan tertinggi adalah dari golongan phenol. Hal ini didukung oleh Ketaren (2008) bahwa pada umumnya antioksidan yang terdapat pada minuman sinom, mengandung struktur inti yang sama, yaitu mengandung cincin benzene tidak jenuh disertai gugusan hidroksil seperti 9-oktadecenoid acid telah diketahui efektif dalam sifat sinergis dari fosfolipid, pengaruh asam sitrat dan asam fosfat terhadap aktivitas antioksidan pada kondisi tertentu. Golongan phenol adalah antioksidan yang dihasilkan dari alam. Berdasarkan urutan aktivitas dan efisiensi dalam menghambat oksidasi, senyawa phenol merupakan urutan yang terakhir dari senyawa lainya. Fraksi air minuman sinom memiliki aktivitas antioksidan tertinggi, diduga karena senyawa yang diduga sebagai penyusun fraksi air ini adalah vitamin $C$ dan vitamin $B_{2}$. Ketaren (2008) yang menjelaskan bahwa beberapa antioksidan dari tipe asam seperti Vitamin C biasanya bersifat sinergi yang berasal dari tipe phenol untuk mengkelat radikal bebas.

Hal ini diduga karena minuman sinom terdiri dari senyawa penyusun antioksidan yang sangat komplek, terdapat kombinasi beberapa jenis antioksidan sehingga lebih tinggi daripada standar. Kumalaningsih (2006) yang menyatakan bahwa dari berbagai antioksidan yang ada, mekanisme kerja serta kemampuan antioksidan sangat bervariasi. Kombinasi beberapa jenis antioksidan memberikan perlindungan yang lebih baik (sinergisme) terhadap oksidasi dibanding dengan satu jenis antioksidan saja.

Tabel 2.Senyawa yang diduga sebagai penyusun fraksi air minuman sinom dengan preparasi TLC

\begin{tabular}{llll}
\hline No. & $\begin{array}{l}\text { Waktu Retensi } \\
\text { (menit) }\end{array}$ & Senyawa-senyawa diduga & $\begin{array}{l}\text { Kadar zat terkandung pada } \\
\text { Fraksi Air } \\
(\mathrm{mg} / \mathrm{ml})\end{array}$ \\
\hline 1 & 0 & ${\text { Vitamin } \mathrm{B}_{1} \text { (thiamine) }}_{3,89}$ & 3,89 \\
2 & 0,09 & Vitamin C(ascorbic acid) $_{3}$ & 1,07 \\
3 & 0,1 & Vitamin $\mathrm{B}_{2}$ (riboflavin) & 3,43 \\
4 & 0,3 & Vitamin C(ascorbic acid) & 2,09 \\
\hline
\end{tabular}

Senyawa yang diduga sebagai penyusun fraksi air minuman sinom dengan metode GCMS 9-Octadecenoid acid, (9,31\%) Pyrrolo (2,3-c) dibenzofuran, $(8,42 \%)$ Hexadecenoid acid, $(4,4 \%)$ Cyclopropaneoctanal, $(2,45 \%)$ Tumeron, $(1,84 \%)$ 4,14 BIS (Hydroxymethyl), (1,31\%) Ar-tumeron, (1,27\%), (1,09\%) Curlon dan Arsenous acid. Senyawa yang terdeteksi dengan metode TLC Ascorbic acid $(32,7 \%)$ dan Riboflavin $(37,1 \%)$. Hal ini diduga bahwa air sering disebut sebagai pelarut universal karena air melarutkan banyak zat kimia yang terdapat pada fraksi air minuman sinom dan senyawa- senyawa diatas memiliki tingkat polaritas yang sama dengan air. Air memiliki polaritas yang tinggi sehingga air hanya menarik senyawa asam amino, jenis-jenis gula dan glikosida dari tumbuhan. Pelarut paling umum digunakan dalam kehidupan sehari-hari adalah air. Pelarut lain yang juga umum digunakan adalah bahan kimia organik (mengandung karbon) yang juga disebut pelarut organik. Pelarut biasanya memiliki titik didih rendah dan lebih mudah menguap, meninggalkan substansi terlarut yang didapatkan. Untuk membedakan antara pelarut dengan zat yang dilarutkan, pelarut biasanya terdapat dalam jumlah yang lebih besar.

Senyawa yang terdeteksi oleh GCMS bersifat polar sehingga dapat diekstraksi oleh pelarut polar seperti air. Pelarut air, aqueous water, aqueous alkal dapat mengekstraksi senyawa kimia seperti gula, asam amino, glikosida, basa asam. Substansi kimia dengan rumus kimia $\mathrm{H}_{2} \mathrm{O}$ yaitu molekul yang tersusun atas dua atom hidrogen yang terikat secara kovalen pada satu atom oksigen (Anonim ${ }^{1}, 2015$ ). Air bersifat tidak berwarna, tidak ada rasa dan tidak berbau pada kondisi standar, yaitu pada tekanan $100 \mathrm{kPa}$ (1bar) dan temperatur 273,15 K. Ekstraksi dengan menggunakan pelarut air memiliki kekurangan yaitu sejumlah besar bahan pengotor juga ikut terambil dan mudah mengalami kontaminasi microbial. Seperti halnya senyawa yang terdeteksi oleh GCMS yang ada pada fraksi air adalah, senyawa 9-Octadecenoic acid $(69.43 \%)$ kemiripanya, hal ini diduga bahwa senyawa tersebut merupakan minyak atsiri (volatile fatty acid) yang memiliki gugus $\mathrm{OH}$ sehingga dikatagorikan sangat potensial sebagai antioksidan.

Ketaren (2008) mendukung pendapat diatas yang menyatakan bahwa, senyawa ini memiliki berat molekul yang rendah sehingga larut dalam air, monounsaturated fatty acidini secara nomenklatur umum digolongkan ke dalam jenis asam lemak oleat yang memiliki rumus molekul $\mathrm{CH}_{3}\left(\mathrm{CH}_{2}\right)_{7}=\mathrm{CH}\left(\mathrm{CH}_{2}\right)_{7} \mathrm{COOH}$ keberadaanya pada sebagian besar minyak dan lemak dan polaritasnya tinggi sehingga digolongkan ke dalam asam-asam 
lemak yang larut dalam air, memiliki titik cair $14^{\circ} \mathrm{C}$ dengan persen beratnya 32,3-41,3 molekul gliserolnya dapat berikatan dengan asam lemak yang berbeda.

Senyawa tersebut diatas diduga merupakan asam lemak tidak jenuh maka, dikatagorikan sebagai asam lemak berisomer $C i s$ yang bersifat tidak stabil, berlangsungnya proses hidrogenasi lebih mudah daripada lemak trans. Hal ini didukung oleh Muchtadi (2012), (Ege, 1994) bahwa senyawa ini merupakan asam lemak tidak jenuh. Asam lemak ini terdapat dalam membran sel dan sifatnya sangat mudah teroksidasi oleh radikal bebas. Keberadaan asam lemak ini paling tinggi pada jaringan dan kontak dengan oksigen, jika teroksidasi akan menyebabkan rusaknya struktur dan fungsi membran sel, karena digolongkan kedalam omega-9 yang digunakan sebagai tanda (marker) adanya defisiensi asam lemak esensial dalam kondisi jika asam lemak omega-3 dan omega-6 keberadaan dalam tubuh sangat kurang.

Ar-tumeron (1.31\%), tumeron $(2.85 \%)$ dan curlon $(1.09 \%)$ dari kurkumin yang larut dalam air tergolong ke dalam kumarin, karenanya dapat dibaca oleh GCMS. Demikian juga dengan vitamin $\mathrm{C}$,vitamin $\mathrm{B}_{2}$, merupakan senyawa yang larut dalam air hanya saja tidak terdeteksi oleh GCMS tetapi oleh TLC. Senyawa yang terdeteksi dengan metode Thin Layer Chromatography (TLC) adalah Ascorbic acid $(32,7 \%)$ dan Riboflavin $(37,1 \%)$ hal ini diduga bahwa senyawa minuman sinom yang terdeteksi adalah senyawa yang memiliki tingkat polaritas yang sangat tinggi sehingga hanya dapat terdeteksi dengan metode TLC, kemungkinan besar memiliki berat molekul yang sangat besar dan bersifat larut dalam air, tidak larut dalam pelarut yang lainya seperti heksana, kloroform, etil asetat, dan sedikit larut dalam pelarut aseton maupun alkohol. Vitamin C sukar larut dalam kloroform, ether, dan benzen. Vitamin $\mathrm{C}$ memiliki berat molekul 178, dalam bentuk kristal dan tidak berwarna, mempunyai titik cair $190-192^{\circ} \mathrm{C}$, stabil pada $\mathrm{pH}$ rendah, mudah teroksidasi jika terdapat katalisator $\mathrm{Fe}, \mathrm{Cu}$, enzim askorbat oksidase, sinar dan temperatur yang tinggi dan oksidasi vitamin $\mathrm{C}$ akan terbentuk asam dehidro askorbat (Muchtadi, 2012). Riboflavin diduga senyawa penyusun fraksi air minuman sinom berasal dari daun asam muda, larut dalam pelarut air karena bersamaan adanya asam askorbat dan juga senyawa penyusun fraksi air yang berasal dari rimpang kunyit yang terasa pahit, Riboflavin sedikit larut dalam air dan sangat mudah larut dalam alkali, juga sedikit larut dalam ethanol dan tidak larut dalam pelarut lemak, namun dapat larut dalam air sedikit berasa pahit, dan stabil dalam larutan asam, asam mineral kuat, maupun oksidator $\left(\right.$ Anonim $\left.^{1}, 2015\right)$. Senyawa yang diduga penyusun fraksi air minuman sinom yang terdeteksi metode TLC adalah flavonoid. Hal ini sesuai dengan hasil penelitian (Wientarsih dan Prasetyo, 2006) bahwa uji minuman sinom yang dilakukan dengan metode kromatografi lapis tipis (KLT) atau TLC yaitu merupakan suatu metode pemisahan suatu senyawa berdasarkan perbedaan distribusi dua fase yaitu fase diam dan fase gerak.

Fase diam yang digunakan ialah plat silika gel yang bersifat polar, sedangkan eluen yang digunakan sebagai fase gerak bersifat sangat polar karena mengandung air. Kepolaran fase diam dan fase gerak hampir sama, tetapi masih lebih polar fase gerak sehingga senyawa flavonoid yang dipisahkan terangkat mengikuti aliran eluen, karena senyawa flavonoid bersifat polar. KLT yang digunakan terbuat dari silika gel dengan ukuran 20 cm x $20 \mathrm{~cm}$ GF254 (Merck).Bahan silika pada umumnya digunakan untuk memisahkan senyawa asam-asam amino, fenol, alkaloid, asam lemak, sterol dan terpenoid. Plat KLT silika gel GF254 diaktifasi dengan cara dioven pada suhu $100^{\circ} \mathrm{C}$ selama 1 jam untuk menghilangkan air yang terdapat pada plat KLT/TLC (Wientarsih dan Prasetyo, 2006)

Hasil fraksi air minuman sinom yang terdeteksi dari Kromatograpi Lapis Tipis (KLT) atau TLC maupun GCMS, diduga bahwa senyawa flavonoid yang tergolong senyawa fenolik tersebut merupakan senyawa polar. Flavonoid merupakan senyawa polar $\left(\right.$ Anonim $\left.{ }^{1}, 2015\right)$ sehingga flavonoid dapat larut dalam pelarut polar seperti etanol, methanol, aseton, dimetil sulfoksida, dimetil fonfamida (DMF), dan air. Flavonoid adalah golongan senyawa bahan alam dari senyawa fenolik yang banyak merupakan pigmen tumbuhan. Saat ini lebih dari 6.000 senyawa yang berbeda masuk kedalam golongan flavonoid. Flavonoid merupakan bagian penting dari diet manusia karena banyak manfaatnya bagi kesehatan. Manfaat kebanyakan flavonoid dalam tubuh manusia adalah sebagai antioksidan sehingga sangat baik untuk pencegahan kanker. Manfaat lain flavonoid adalah untuk melindungi struktur sel, memiliki hubungan sinergis dengan vitamin $\mathrm{C}$ (meningkatkan efektivitas vitamin C), anti inflamasi, mencegah keropos tulang, dan sebagai antibiotik (Muchtadi,2012).

Tabel 1 menunjukkan bahwa persen relatif masing-masing pelarut ini berbeda. Senyawa yang mempunyai persen relatif yang sama adalah artumeron yang larut dalam pelarut air. Senyawa yang diduga sebagai penyusun minuman sinom kemugkinan mempunyai nilai polaritas yang sama dengan pelarutnya.

Ketaren (2008) menegaskan bahwa suatu zat dapat larut dalam pelarut jika mempuyai nilai 
polaritas yang sama, yaitu zat polar larut dalam pola pelarut bersifat polar dan tidak larut dalam pelarut

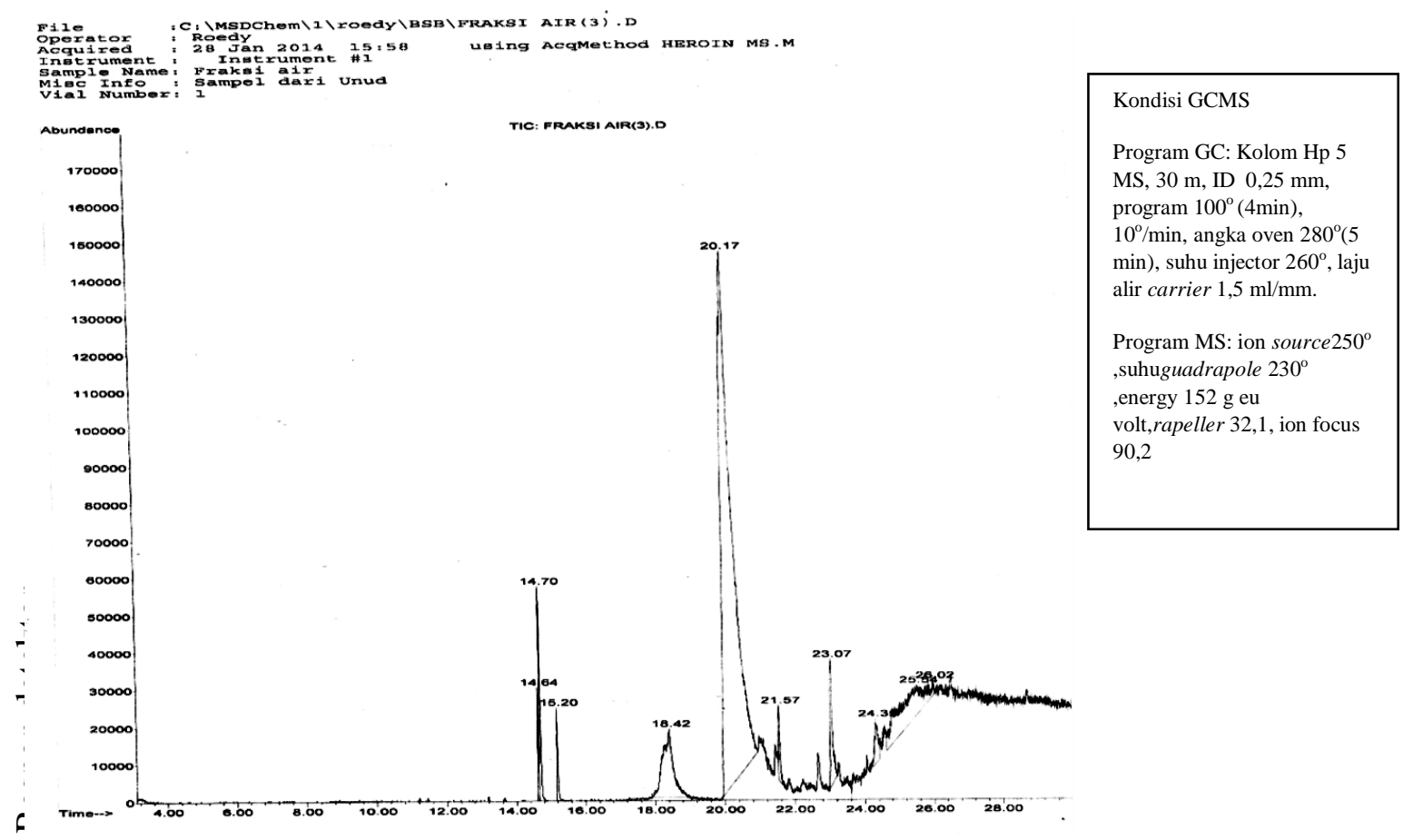

Gambar 2.Kromatogram fraksi air minuman sinom

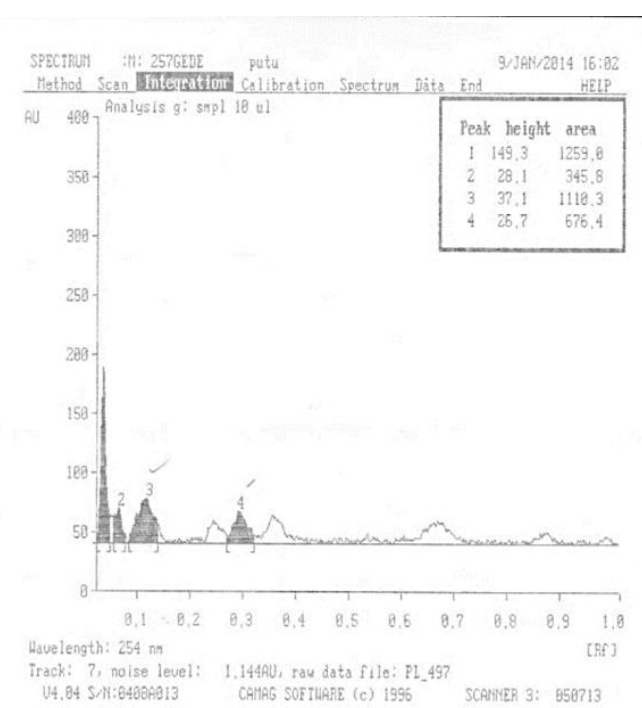

Gambar 3. Kromatogram fraksi Air minuman sinom TLC -spektrofoto densitometry 
Hasil analisis senyawa yang diduga terkandung dalam fraksi hasil identifikasinya disajikan pada Tabel 3 . Tabel 3. Senyawa yang diduga penyusun fraksi air minuman sinom dngan metode GCMS

\begin{tabular}{cccc}
\hline No. & Waktu & Senyawa & Persen Relatif \\
& Retensi & & \\
\hline 1 & 14.62 & Ar Tumeron & 1.31 \\
2 & 14.69 & Tumerone & 2.85 \\
3 & 15.19 & Curlone & 1.09 \\
4 & 25.8 & Cyclotrisiloxane & - \\
5 & 13.18 & Pyridine & - \\
6 & 16.13 & 1,2,3,5-tetramethyl propenoate-2- & - \\
7 & 16.46 & (E)-2-methylbut-2 & - \\
8 & 16.76 & 2-chloro-1 & - \\
9 & 16.85 & m-Fluoroanisole & - \\
10 & 13.17 & 1-methyl-4-(1-methylethyl) & - \\
11 & 15.97 & Cyclohexene & - \\
12 & 16.07 & 3-Methyl-2-butenoic acid & - \\
13 & 16.13 & Benzene & - \\
14 & 16.47 & Cyclohexane & - \\
15 & 16.69 & 7-Propyl-cis-bicyclo\{3.2.0\} & - \\
16 & 17.58 & Benzenemethanol & - \\
17 & 17.81 & 2-Pyrazoline & - \\
18 & 18.4 & 1,2-Benzenedicarboxylic acid & - \\
19 & 18.75 & 1-Isopropenyl-3 & - \\
20 & 21.56 & 1-Piperidinepropanol & - \\
21 & 18.42 & n-Hexadecanoic acid & 8.42 \\
22 & 20.17 & 9-Octadecenoic acid & 69.43 \\
23 & 21.57 & 1-Piperidinepropanol & 1.27 \\
24 & 23.07 & Cyclopropaneoctanal & 3.4 \\
25 & 24.35 & 4,14 BIS (Hydroxymethyl) & 1.84 \\
26 & 25.54 & Pyrrolo\{2,3-c\}dibenzofuran & 9.31 \\
27 & 26.02 & Arsenous acid & 1.09 \\
28 & 1110.3 & Ascorbic Acid *) & 32.7 \\
29 & 1259 & Vit.B (Riboflavin) *) & 37.1 \\
\hline & &
\end{tabular}

Keterangan :- tidak terdeteksi, *) terdeteksi dengan metode TLC

\section{SIMPULAN DAN SARAN}

\section{Simpulan}

Kapasitas antioksidan yang paling tinggi dari ke -4 has

il fraksi berbagai pelarut adalah kapasitas antioksidan dari hasil fraksi air yaitu 199.100 $\mu \mathrm{g} \mathrm{AAEAC/g}$ atau 1991 ppm AAEAC dengan nilai rata-rata rendemen adalah $10,94 \%$.

Senyawa yang diduga sebagai penyusun fraksia air minuman sinom dengan metode GC-MS adalah :9-octadecanoid fatty acid (69,43\%), nhexadecenoid acid $(8,42 \%)$ tumerone $(2,83 \%)$, artumerone $(1,31 \%)$, curlone $(1,09 \%)$, dan vitamin $\mathrm{C}$ $(32,7 \%)$,Vitamin B $(37,1 \%)$ pada fraksi air.

\section{Saran}

Identifikasi hasil fraksi minuman sinom perlu diuji dengan menggunakan HPLC

\section{UCAPAN TERIMAKASIH}

Terimakasih yang sebesar-besarnya kepada LP2M Universitas Dhyana pura, dan Yayasan Universitas Dhyana Pura yang sudah membantu dana penelitian ini.

\section{DAFTAR PUSTAKA}

Anonim $^{1}$, 2015. Tabel sifat-sifat pelarut uтит. Dalam https://www.scribd.com/doc/131923261/Ta bel-Sifat_Pelarut.Diakses tanggal 21 Desember pukul 22.30 WIB.

Firdaus $^{1}$, Rimbawan ${ }^{2}$, Sri Ana Marlianti ${ }^{2}$, Katrin Rosita $^{2}$. 2016. Model Tikus Diabetes yang Diinduksi Streptozotocin-SukrosaUntuk Pendekatan Penelitian Diabetes Mellitus. Jurnal MKMI, vol 12 no 1.

Istiani, C. 2011. Deteksi adanya Pemalsuan Minyak Kunyit dengan Pengujian Putaran Optik menggunakan Polarimeter tipe WXGU. Universitas Diponogoro. Semarang

Julianto, E. 2015. Efektivitas Hidrokoloid Kunyit (curcuma dommestica) Terhadap Proses 
Penyembuhan Luka Diabetik Stadium I Tikus (rattus novergitus).Jurnal Husada Mahakam.4:1-17

Muhtadi.,et al. 2014. Pengujian Daya Antioksidan dari Beberapa Ekstrak Kulit Buah Asli Indonesia Dengan Metode FTC. Simposium Nasional RAPI XIII, 1412-9612

Ganong,W.F. 2008. Buku Ajar Fisiologi Kedokteran. Editors Edisi Bahasa Indonesia. Ed.22-Jakarta :EGC 347- 367

Guyton dan Hall. 2007. Buku Ajar Fisiologi Kedokteran. EGC Medical Publisher. Jakarta. (3) 41-459

Guyton, A.C., J.E.Hall, Joh . 2012. Buku Ajar Fisiologi Kedokteran. Edisi 11. Penerbit Buku Kedokteran: EGC P 37-459

Kumalaningsih, S.2006. Antioksidan Alami. Trubus Agrisarana, Surabaya

Lukita-Atmadja W., Y.Ito, G.L.Baker., and R.S.McCuskey. 2002. Effect of curcuminoids as anti-inflammatory agents on the hepatic microvascular response to endotoxin.SHOCK. 17 (5): 399-403.

Mulyani, S., K.Satriawan, dan IGA.L. Triani. 2006. Potensi Minuman Kunyit- Asam (Curcuma domestica Val - Tamarindus Indica L.) Sebagai Sumber Antioksidan Beserta Analisis Finansialnya, Laporan Research Grant, TPSDP. ADB- LOAN

Olivia, F., S.Alam, and I.Hadibroto. 2006. Seluk Beluk Food Supplement. Jakarta: Penerbit PT Gramedia Pustaka Utama, p: 166.
Sofia,Z,;Mohammed,C,;Ahmed,J: Effek of Polar and Nonpolar solvent on total phenolic and antioxidant activity of roots extracts of Carraluma europaea Der Pharma Chemica 2016,8(11)191-196

Straine TW,Okoro CA, Chapman DP, Beckles G, Balluz L, Mokdad AH. The Impact of Formal Diabetes Education on The Preventive Health Practices and Behaviors Of Peson with Type 2 Diabetes, (serial online) 2005 July (cited 2015 January).Available from: www.ncbi.nlm.nih.gov/pubmed/15916996

Suryani,N., T.H.Am.A. Endang. 2013. Pengaruh Ekstrak Metanol Biji Mahoni terhadap Peningkatan Kadar Insulin,Penurunan Ekspresi TNF- $\alpha$ dan Perbaikan Jaringan Pankreas Tikus Diabetes. Jurnal Kedokteran Brawijaya,vol.27., 137-145

Susanti, A. 2009. Inhibisi ekstrak air dan Etanol Daun asam Jawa dan Rimpang Kunci pepet terhadap Lipase Pankreas secara Invitro. Departemen Kimia fakultas Matematika dan ilmu Pengetahuan alam. Institut Pertanian Bogor.Bogor.

Ukil A., S.Maity, S.Karmakar, N.Datta, J.R.Vedasiromoni, and P.K.Das. 2003. Curcumin, the major component of food flavour turmeric, reduces mucosal injury in trinitrobenzene sulphonic acid-induced colitis. British Journal of Pharmacology. 139: 209-18. 
Kusumaningsih.P.,Wiradnyani.N.K / Kesehatan Terpadu 3(1) (2019) 